\title{
A Lei e o Corpo
}

\author{
Antoinette Chauvenett*
}

\begin{abstract}
"Nossas ciências sociais podem nos tornar muito sábios ou muito hábeis, quando se trata de encontrar os meios que nos permitirão atingir qualquer objetivo a que possamos nos propor. Mas elas admitem que não nos são de nenhuma serventia tão logo se trate de distinguir entre objetivos legítimos ou ilegítimos, justos ou injustos. São instrumentos e nada além disso. Nasceram para servir a todos os poderes, a todos os interesses, sejam eles quais forem. ${ }^{\cdot 1}$
\end{abstract}

Afirmar a proposição sociológica segundo a qual a doença é um fato cultural, analisável enquanto fato social total, é admitir a arbitrariedade dessa noção e dos fenômenos por ela encobertos. Atualmente, esta arbitrariedade surge para nós em função da revolução epistemológica que a doença experimentou ao longo de várias décadas e, principalmente, em função de sua explosão. $\mathrm{O}$ isolamento da categoria doença, as teorias explicativas que dão conta dela, as manifestações e os sinais selecionados para diferenciá-la da não-doença, as filosofias e as ideologias que servem como lugar às suas representações, estão imersas atualmente em grande confusão. A extensão desse conceito a fatos que ultrapassam o campo de sua aplicação tradicional - o corpo - nos leva a constatar o desuso da noção de doença.

* Antoinette Chauvenet, socióloga, Centre d'Étude des Mouvements Sociaux, CNRS, Maison des Sciences de l'Homme, 54 Boulevard Raspail, 75270, Paris. Tradução do original La loi et les corps feita por Silvia Alexim Nunes.

1. StRAuSS L., Drvit nuiurel et histoire, Plon, 1954, p. 16. 
Ao lado do conceito de doença, explicativo de fenômenos bem circunscritos e sustentado por uma profissão em situação de monopólio, aparecem outros esquemas explicativos que se apóiam em numerosos sinais, utilizam conceitos como marginalidade, segurança, risco, necessidade, proteção, garantia e saúde e são postos em prática pelas profissões recentemente aparecidas.

O recurso a tais conceitos contribui para o alargamento e a explosão da noção de doença, pondo fim a uma certa ordem, estabelecida pela filosofia da ontologia vitalista. Segundo esta filosofia, o ser vivo definia em seu próprionível suias normas de funcionamento, equilíbrio e evolução. Esta filosofia conferia ao ser vivo, assim como à doença, um estatuto autônomo e separado. Ela assinalava ao mesmo tempo um lugar isolado à medicina na batalha histórica, no seio da qual tomou forma a filosofia social de onde procedem o estatuto da pessoa e do papel social.

O Direito foi o lugar de elaboração desta filosofia. Ele foi, por sua vez, a instância de formalização das regras positivas do funcionamento social e de sua sanção e o lugar de enunciação dos princípios universais responsáveis pela justiça social e pelos intercâmbios sociais, funcionando, como o disse Claude Lefort, "como sistema simbólico e como princípio gerador de uma democracia". Este lugar privilegiado do Direito necessita de uma concepção objetiva da Razão. Ela procedia da afirmação dupla do direito natural e da razão natural.

A explosão da noção de doença traduz um fato contemporâneo marcante: a penetração das ciências sociais e das ciências do homem no campo que definia a doença e a rápida expansão de profissões que fundam sua prática nos conhecimentos positivos que produzem estas ciências. Traduz, sobretudo, uma nova perspectiva cultural do corpo, da pessoa e do papel social. Hoje em dia, as ciências do ser vivo, as ciências do homem e as ciências sociais são partes ligadas na definição cultural da responsabilidade individual e do campo do exercício da liberdade das pessoas. Esta definição dependia da competência dos juristas: as ciências do homem tendem a reservar ao Direito um papel de príncipe. Assiste-se, com efeito, já há vários decênios, ao declínio do Direito e da lei jurídica impessoal e geral em proveito de uma extensão de direitos especiais, de um direito estatutário e do direito regulamentar. Este declínio é paralelo ao desenvolvimento das ciências sociais e das ciências do ser vivo, à sua participação crescente, à definição da Lei. Constatase que estas ciências ocupam atualmente posição que lhes permite estabelecer normas relativas ao relacionamento conjugal ou ao relacionamento entre gerações, e que a saúde é o resultado suposto da observação de prescrições múltiplas em matéria de higiene ou de modo de vida. A pedagogia não escapa a esse tipo de normalização.

Tudo isso nos obriga a considerar a doença como uma categoria histórica, ligada a un certo quadro socio-cultural. E a análise desse vínculo que nos deve 
permitir dar conta da transformação dessa categoria. Parece-nos necessário pesquisar como essa irrupção das ciências do homem e do ser vivo no campo da doença tornou-se hoje em dia um jogo considerável para a epistemologia da medicina e para seu objeto. Porque parece-nos igualmente necessário compreender em quais condições se faz atualmente a abertura da noção de doença, abertura que coloca a medicina em posição de aplicar uma nova compreensão cultural do relacionamento do homem com a sua pessoa, com as leis que estabelecem as ciências da qual ela faz parte. Que filosofia social, que idéia de ética e de justiça estão na base dessa posição? Que estatuto da razão e do conhecimento elas adquiriram, que idéia de História e de sentido ela veicula?

Podia causar arrependimento o abandono, durante muito tempo, da batalha política do Direito e dos direitos do homem, porque seu papel como sistema simbólico e filosófico foi negado ou subestimado. Mas parece urgente não abandonar a batalha politica aberta pela extensão do recurso às ciências do homem e do ser vivo dentro da gestão do social e da cena política.

Se essas questões pareciam desmesuradamente ambiciosas, parece-nos necessário ao menos colocá-las justamente no seu conjunto e em suas principais interrelações, a fim de não permanecer aprisionadas em categorias tornadas obsoletas, nem restritos a uma especialização que perdeu sua razão de ser, já que oque está aqui em jogo são perturbações sócio-culturais que atravessam o conjunto do universo social e cultural.

\section{I - DOENÇA, NORMA E SENTIDO}

\section{1. $O$ arbitrário cultural da noção de doença}

A antropologia nos ensina que, assim como a lei jurídica não é um produto necessário da vida em sociedade, em nenhuma cultura a doença pode ser concebida enquanto realidade biológica em si.

- Assim, a doença pode não ser diferenciada de outros infortúnios: é o caso entre os Ogori, na Nigéria. ${ }^{2}$

- Quando existe uma certa idéia da doença, as representações que os indivíduos têm de suas causas podem basear-se na observação de sinais físicos (ou sintomas) ou serem totalmente independentes em relação a eles. Os Gnau, na Nova Guiné, por exemplo, classificam as doenças não em função de suas manifestações, mas a partir de suas causas. A causa e o remédio dependem de um sistema de

2. Ver GILLIES E., Causal Criteria in African Classification of Disease. Sorial Anthrnpningy ana Medicıne, Academic Press, 1976. 
evidências distinto daquele dos estados do corpo. Os Gnau são maus conhecedores de ervas. Eles não utilizam ervas específicas, cujo uso estaria ligado a sinais clínicos observados. Por outro lado, utilizam uma multiplicidade de plantas por ocasião de rituais de tratamento, embora poucas delas entrem em contato com o corpo. Sejam elas comidas ou aplicadas ao corpo, seu uso depende da identificação da causa e está ligado a um saber complexo sobre as relações existentes entre as plantas e os espíritos. Estas causas pertencem à ordem da magia, da bruxaria e dos espíritos. ${ }^{3}$

- A explicação do sintoma pode depender de várias ordens de explicação.

Entre os Azande, por exemplo, a explicação pela bruxaria coexiste com uma explicação de caráter empírico. ${ }^{4} \mathrm{~A}$ ideologia social determina que tudo o que se relaciona com os homens tem uma causa humana. Quando um individuo cai doente ou morre, alguém desejou, quis ou provocou sua doença ou sua morte. Esta visão das coisas não impede que aos Azande façam remédios especificos para as doenças identificadas, remédios cuja composição está ligada às doenças conhecidas pelos seus sintomas. Do mesmo modo, as classificações das doenças podem ser construídas a partir de critérios dependentes de níveis múltiplos de interpretações, que podem se acumular, se excluir ou se opor.

Estas poucas indicações propostas pela antropologia mostram a necessidade de considerar a doença como uma categoria cultural relativa. Esta relatividade se manifesta em diferentes níveis.

Por um lado, quando a idéia de doença é diferenciada de outros infortúnios, as interpretações podem ignorar totalmente os estados do corpo. Este é apenas um receptáculo em um sistema de relações que liga os homens ao mundo vegetal e ao mundo simbólico. Entre os Zande, ao contrário, assim como entre os Wolofs, por exemplo, a coesão e a ordem social estão diretamente inscritas no corpo dos indivíduos. Tudo o que diz respeito aos estados do corpo coloca em jogo as relações sociais e o simbolismo da sociedade.

A. Zempleni ${ }^{5}$ mostra de que forma, entre os Wolofs, a existência de operadores simbólicos - por exemplo a idéia de possessão por um ancestral - inscreve a ameaça de desintegração de um grupo social, a linhagem nesse caso, no corpo dos indivíduos. É a apreensão da doença ou da magia que sanciona a norma de

3. Ver LEWIS G., Social Anthropology and Medicine, Academic Press, 1976.

4. Ver Evans-Pritchard E.E., Sorcellerie, oracles et magie chez les Azandé, Gallimard, Paris, 1972.

5. ZEMPLENI A., "Mal de soi, mal de l'autre", Autrement. Guérir pour normalisir, nº 4, pp. 75- 10. 
comportamento entre os iguais sociais: a interpretação mágica dos males do indivíduo é também o meio de nivelamento de suas relações com os seus iguais... ou um procedimento de normalização de seus comportamentos sociais. Mas tratase de um procedimento sutil que se apodera da angústia do doente - uma sanção aleatória - para fazê-lo reassumir, em toda a sua afetividade, as normas de conduta que garantem a manutenção da estrutura da sociedade.

Por outro lado, a doença, como outras adversidades, pode estar em relação direta com uma perturbação ou uma ruptura da ordem social. Ela é então a sanção de uma infração moral e de um delito. Assim, a doença pode ser a marca da lei no corpo. Mas a relação da lei com o corpo pode dispensar a doença: é o que ocorre com o castigo corporal, com a tortura iniciatória, com a tatuagem ou ainda com o sacrifício humano. Segundo P. Clastres 6 , pela tortura iniciatória, o iniciado, novo sujeito da lei, consolida o corpo social carregando, não mais sozinho mas como todo sujeito, a marca da lei. A função da tortura iniciatória é marcar o corpo: “A sociedade dita sua lei aos seus membros, inscreve o texto da lei na superfície dos corpos. Pois a lei que funda a vida social da tribo não pode ser esquecida por ninguém." No mesmo sentido, aquele que incitou o corpo social à destruição através de um ato do qual é reconhecido como culpado pode ser colocado fora da lei, em um espaço separado, fechado, que o arranca do corpo social (prisão, campo de reclusão...). Nesses casos, a marcação espacial pode ser redobrada por uma marcação sobre a pessoa: o indivíduo pode ele mesmo inscrever a lei sobre seu corpo, seja pela morte, pela loucura, pela doença ou pela tatuagem, indiferentemente. P. Clastres ${ }^{7}$, citando Martchenko (Mon Témoignage), diz que nas colônias penais da Moldávi, a tríplice aliança entre a lei, a escrita e o corpo, levada ao seu ponto extremo de estreitamento, abole a própria necessidade da máquina. Ou melhor, é o prisioneiro que se transforma em máquina de escrever a lei e que a inscreve sobre seu próprio corpo. Para enunciar-se, a dureza da lei encontra a mão, o corpo do próprio culpado-vítima.

A violação da norma pode chegar a uma outra forma extrema de castigo que se conclui pela morte do culpado, onde nenhuma mão, nenhuma doença intervêm. M. Mauss ${ }^{8}$ evoca o caso, na Austrália, em que o sujeito que morre não se considera ou não se sabe doente e se acha apenas, por motivos coletivos precisos, em um estado próximo da morte. Este estado coincide geralmente com uma ruptura de

6. CLASTRES P., La société contre l'Etat. Ed. de Minuit, Paris, 1974.

7. CLASTRES P., La société contre l'Etat, op. cit.

8. MAIISC M, Smoningie er amoloropologic, r.U.r., 1950. 
comunhão, seja pela magia, seja pelo pecado, com as potências e as coisas sagradas, cuja presença normalmente o sustenta. "A consciência é então completamente invadida por idéias e sentimentos que são de origem inteiramente coletiva e que não trazem nenhuma perturbação mental individual, fora da sugestão coletiva." Este indivíduo se acha encantado ou em infração e morre por esta razão. M. Mauss evoca também o caso dos neozelandeses, entre os quais apenas a moralidade (e não o encantamento ou o enfeitiçamento) é a causa da maioria das mortes.

Em outras palavras, a função desempenhada pelo corpo na sociedade é um fato cultural muito variável. O objeto desta função pode ser o sistema de representações simbólicas, nas quais o corpo pode ocupar um lugar central ou marginal, ou então a lei das relações sociais. A doença surge como uma categoria relativa. Ela pode servir de causa ou de mediação, uma espécie de objeto 'transicional' do envolvimento do corpo no sistema de representações ou na lei social. Em outros casos, a relação entre a lei social e a doença pode ser direta. Ela pode, enfim, quando não se diferencia de outros infortúnios, não dar lugar a efeitos simbólicos ou sociais especificos.

Queremos mostrar aqui, a partir de um esboço rápido da história contemporânea da noção de doença, que parece estar sendo recriado um modelo no qual a doença enquanto categoria específica dependia de um sistema de representações que excluía o social e a questão do sentido. Hoje, com a irrupção massiva das ciências sociais em um novo campo de representações (o da saúde), articula-se um sistema de representações onde o sentido ocupa um lugar central, senão tirânico, colocando diretamente em jogo a ordem e as relações sociais. Nesta análise, apoiarnos-emos na obra de G. Canguilhem, Le normal et le pathologique ${ }^{9}$, que analisa a filosofia da corrente vitalista na medicina.

\section{Da autonomia do ser vivo à saúde como Nomos constitutivo da lei}

\section{a) A afirmação de uma ontologia vitalista}

Definir as estruturas patológicas como um conjunto - com a idéia subjacente de que existe uma ordem entre fenômenos que não têm, $a$ priori, uma relação necessária entre si - para opô-lo ao normal, é operar um corte da realidade que a organiza a partir de uma unidade. Esta unidade é a normatividade do ser vivo. Eis a afirmação da posição vitalista: o patológico só retira sua unidade do ser vivo, que define, no seu nível, as normas, as cria, as faz evoluir. Uma vez enunciada a ontologia vital enquanto fonte de normatividade do ser vivo, todos os dados da

9. CANGUILHEM G., Le normal et le pathologique, P.U.F., Galien, 1966. 
ordem social ou psicológica vêm se subordinar a esta normatividade: "Se é verdade que o corpo humano é, em um certo sentido, o produto da atividade social, não é absurdo pensar que a estabilidade de certos traços revelados pela média depende da fidelidade consciente a certas normas de vida." ${ }^{10}$

\section{b) A normatividade do ser vivo}

Em G. Canguilhem, as noções de norma vital e de média são identificadas. É bem verdade que o autor nos diz que a estatística não fornece nenhum meio para decidir se o afastamento em relação à média é normal ou anormal. Mas ele atribui um certo valor à média através da noção de constantes fisiológicas, constantes estas que realizam um optimum. "As constantes apresentam-se com uma freqüência e um valor médio em um grupo determinado, o que lhes dá valor de normalidade. E esta normalidade é verdadeiramente a expressão de uma normatividade: a constante fisiológica é a expressão de um optimum fisiológico nestas condições determinadas, entre as quais é preciso conservar aquelas que o ser vivo em geral e o homo faber, em particular, se atribuem."11

Estabelecendo a independência lógica dos conceitos de norma e de média, ele formula a hipótese de que esta ligação pode ser explicada pela subordinação da média à norma: as médias têm por princípio normativo hábitos humanos em relação aos tipos e ritmos de vida". "Um traço humano não seria normal porque freqüente, mas freqüente porque normal, isto é, normativo em um tipo de vida determinado...". ${ }^{12}$

\section{c) A negação da doença e a necessidade terapêutica}

A teoria vitalista só pode se afirmar negando a doença e a morte. A doença só é apresentada do ponto de vista do doente através da possibilidade que tem o ser vivo de tolerar as infrações à norma habitual, de instituir normas novas e novas situações. Estas normas são constantes fisiológicas a serviço de um equilíbrio ótimo. A doença, na corrente vitalista, retira o seu estatuto apenas de uma possibilidade de restauração da saúde. O patológico é somente uma negatividade momentânea. O normal é a saúde. Afirmando-se, o princípio vitalista pratica a denegação da doença e da morte. No máximo, leva em conta a instabilidade relativa das constantes fisiológicas e a importância dos estados de falsos equilibrios

10. CANGUILHEM G., Le normal et le pathologique, op. cit., p. 102.

11. CANGUILHEM G., Le normal et le pathologique, op. cit., p. 111

15 cancUilhim G., Le muimai er ie puifiologique, op. cir., p. 102. 
adaptadores para a explicação das doenças e das mutações. Um ponto de vista como este traduz uma filosofia otimista do vital: o organismo se encaminha para a vida, não para a morte. No entanto, o paradoxo, muitas vezes assinalado, da medicina, é o de ter que curar quando não se pode mais curar, isto é, quando a natureza não é suficiente. Assim, a filosofia vitalista do equilíbrio ótimo só pode se sustentar quando se a afirma o ponto de vista contrário, segundo o qual não se pode esperar nada de bom da própria natureza. É este último que fundamenta a necessidade terapêutica (que desapareceria em uma perspectiva estritamente otimista do vital).

De fato, G. Canguilhem aponta a necessidade terapêutica como ponto de partida de uma teoria ontológica da doença: sem dúvida, diz ele, é à necessidade terapêutica que é preciso atribuir a iniciativa de toda teoria ontológica da doença. Ele mostra também que a necessidade terapêutica se apóia no fato de que não se espera nada de bom da própria natureza. Ele diz, finalmente, que é a necessidade terapêutica que está no ponto de partida da normatividade do ser vivo: "Na medicina, o estado normal indica ao mesmo tempo o estado habitual dos órgãos e seu estado ideal, pois o restabelecimento deste estado habitual é o objeto ordinário da terapêutica." 13

\section{d) Norma e conhecimento}

O autor sustenta em toda sua obra a posição vitalista a partir de uma concepção ontológica autônoma do vital, e não a partir da necessidade terapêutica. O otimismo dessa filosofia pressupõe um otimismo diante do agir médico, a possibilidade de uma intervenção na ordem das coisas definida pela razão médica. É de fato esta última que, em definitivo, define o normal e o patológico e fundamenta o princípio da normatividade vital.

Nessa perspectiva a doença e o patológico definem o ponto de vista médico, em detrimento do ponto de vista do paciente. $G$. Canguilhem observa que a doença é diferente de uma ausência momentânea: "A doença existe de fato em algum lugar, pelo menos para o doente, o patológico implica a noção de pathos enquanto sentimento concreto de sofrimento, de impotência e de vida contrariada"; no entanto, ele conclui deste modo: "Mas o patológico é na verdade o anormal, isto é, uma negatividade momentânea." ${ }^{14}$ Segundo a razão médica, as idéias de doença e de patologia não podem ser compreendidas ao mesmo tempo sob o ponto de vista

13. CANGUILHEM G., Le normal et le pathologique, op. cit., p. 77

14. CANGUILHEM G., Le normal et le pathologique, op. cit., p.85. 
do médico e sob o ponto de vista do doente. Como diz J. Chavreul: ${ }^{15}$ "Não se pode pretender salvar ao mesmo tempo o discurso médico e o discurso do paciente (...) Ao se estabelecer definitivamente enquanto ciência, a medicina nos deixa subjetivamente divididos."

Em outras palavras, é a necessidade terapêutica, cujo campo de aplicação é circunscrito pela medicina, e à qual vem responder a queixa do doente, que fundamenta a ontologia vitalista. Nunca seria demais insistir, como lembra C. Lefort ${ }^{16}$,"no duplo caráter da idéia, que é representação e norma". De um lado, há a escolha cultural relativa à representação da doença como ontologia biológica, isto é, a afirmação filosófica da autonomia do vital. Por outro lado, há a normatividade de onde emana a ação médica, normatividade que circunscreve o seu campo de atuação, a ordem médica e, através desta, a ordem dos corpos. A representação deste campo separado e autônomo do vital define os limites da especificidade médica, assim como sua legitimidade. A norma vital é a condição de existência de um campo autônomo do conhecimento: a ordem médica institui a ordem do ser vivo.

\section{e) Vitalismo e positivismo}

Por sua importância, esta obra provocou um novo interesse pela corrente vitalista, fortalecendo o ponto de vista médico sobre a doença, quando a medicina parecia sofrer de uma espécie de depressão epistemológica, em função da concorrência de outras filosofias da doença oriundas da psicanálise. Estas podiam pretender dar um outro estatuto à doença, porque integravam o ponto de vista do doente $\mathrm{e}$ fundamentavam sua terapêtica nos fatos. A corrente vitalista, baseandose no neodarwinismo renascente que gozava de grande fama na época das teorias da hereditariedade biológica, podia tornar menos incerta a filosofia médica, articulando-a estreitamente aos resultados espetaculares da biologia humana. G. Canguilhem afirmava esta filiação: "Dizer que a hereditariedade biológica é uma comunicação de informação é admitir que há no ser vivo um logos inscrito, conservado e transmitido... Definir a vida como um sentido escrito na matéria é admitir a existência de um a priori objetivo, de um a priori propriamente material e não mais apenas formal." Esta posição, que realiza um retorno ao positivismo, do qual pretendia se afastar, foi revelada por D. Lecourt. ${ }^{17}$ Segundo ele, o vitalismo

15. Cha VReUl J., L'ordre médical, Seuil, Le champ freudien, Paris, 1978.

16. LEFORT Cl., Les formes de l'Histoire. Essais d'anthropologie politique, Gallimard, 1978.

17. LELUUK। D., Pour une critique de l'épistémologie, Maspério, Théorie, 1972. 
de C. Ganguilhem torna-se uma filosofia da vida e, ao mesmo tempo, uma teoria do conhecimento. "A filiação que vai da vida ao conceito pela mediação do conceito da vida não nos parece de modo algum legitimada pela existência material efetiva dos ADN" (...) “Curto-circuitando vida e conceito, em nome deste a priori natural, não se está tomando um lugar no campo das teorias empiristas do conhecimento? Um empirismo especulativo, sem dúvida, pois é o logos que deve dar conta de si mesmo e de sua concepção, mas um empirismo assim mesmo, com o perigo, que se anuncia bem demais aqui, de ver desaparecer a fonte objetiva do conhecimento".

Resumiremos sumariamente as críticas que podem ser feitas ao positivismo, críticas que podemos dirigir a todos os campos do conhecimento para os quais a cientificidade é reivindicada: o positivismo reduz a dimensão histórica dos fenômenos estudados a uma evolução dotada de um sentido exterior ao sujeito e preestabelecido, linear e cronológico; uma evolução que leva o conhecimento do erro à verdade, onde todas as verdades são julgadas a partir da mais tecente delas. Os fenômenos entre os quais ele estabelece relações existem ontologicamente, independentemente da relação que o observador trava com eles. $O$ recurso à explicação pela origem, correlato da perspectiva evolutiva, nega a dimensão possível do sujeito enquanto ator de sua própria história, isto é, sua liberdade. Nesta perspectiva, a ação é ilusória. $O$ discurso positivista separa julgamento de valor $e$ julgamento de conhecimento. Estabelece um corte entre moral e conhecimento, evitando questionar o sentido através do conhecimento objetivo. Fazendo isso, ele hipostasia o ato de conhecimento científico enquanto valor último, produtor do único sentido possível. Submetendo-se aos conhecimentos produzidos como fonte única de verdade, dá um estatuto objetivo à razão. Nesta medida, a razão serve o interesse do sujeito, isto é, a conservação de si, conservadorismo do indivíduo ou da espécie, conservadorismo social. Criticando a razão moderna, Horkheimer e Adorno ${ }^{18}$ aplicam este golpe de misericórdia: “A razão é mais totalitária do que qualquer sistema: para ela, todo processo está determinado desde o início, toda esperança é retirada, não da realidade, mas do saber, que no símbolo mítico ou matemático se apropria da realidade como esquema e a perpetua enquanto tal."

Estas críticas podem ser geralmente dirigidas ao positivismo quando ele se aplica a uma natureza que se deixa doar e reduzir. Mas, na medicina, a presença da

18. ADORNO T. e HORKHEIMER M., La dialectique de la raison. Fragments philosophiques, Gallimard, 1974. 
morte, a resistência da matéria e o fracasso sempre possível obrigaram durante muito tempo a uma modéstia maior. A presença do doente por detrás da doença é uma evocação constante do indeterminado da natureza. "A natureza faz o que quer e zomba de nossas generalidades que só podem se aplicar a ela, única, incomparável e sempre diferente no curso do desdobramento aventuroso de sua história sem historiador." 19

O vitalismo, mesmo tendo G. Canguilhem estabelecido sua filiação ao positivismo, não se reduz a ele. Isto é verdadeiro quando reconhece a necessidade terapêutica, quando se afirma enquanto filosofia, isto é, enquanto interrogação fundamental. É verdadeiro sobretudo quando, negando a morte e a presença da morte na doença, ele afirma a criatividade do ser vivo, definindo a doença como "um outro procedimento da vida". Enquanto filosofia, o ponto de vista vitalista enquanto filosofia implica que a medicina seja concebida como arte, isto é, como uma prática que reconhece a doença em sua criatividade, ao contrário do ponto de vista cientificista atual da medicina, que busca somente reduzi-la. Nestas condições, a posição vitalista pode preservar este elemento essencial: a idéia da inacessibilidade da vida e da impossibilidade de domá-la. A ontologia vitalista, concedendo um estatuto autônomo e separado ao ser vivo, garante ao mesmo tempo a possibilidade de sua liberdade, do mistério, até mesmo do absurdo: a idéia de autonomia funciona de fato como um princípio explicativo externo, isto é, como atestado inacessível à razão. Nisso ela se distingue das representações historicistas atuais da doença, que fazem desta uma história predeterminada, fazendo do doente o historiador de uma doença que não the pertence. ${ }^{20}$ Nesta perspectiva, a posição vitalista pode ser aparentada às diversas filosofias do Ocidente que reconhecem, como faz opensamento mítico, a dominação da natureza ou de Deus - "Eu o tratava, Deus o curou", dizia Ambroise Paré - enquanto o ponto de vista positivista pretende que a razão científica possa dominar o mundo: "A razão se opõe ao mito que reconhece a dominação da natureza, pretendendo a razão dominar o mundo", disseram M. Horkheimer e T. Adorno ${ }^{21}$

19. REGNIER A., La crise du langage scientifique, Anthropos, Paris, 1974.

20. Este princípio de separação essencial tem analogias com o princípio de separação do Direito e da Moral. Ele tinha como efeito poupar, dentro de certos limites (aqueles das representações), uma autonomia da pessoa e um certo espaço de liberdade juridicamente protegido.

21. ADORNO T. с HORNHEIMEK M., La dialectique de la raison, op. cit. 


\section{II - CAUSALIDADE E DESVIO}

A revolução cultural no seio da qual explodiu a noção de doença se produziu, no nosso entendimento, em torno da necessidade de sentido e da busca das causas da doença. A medicina foi criticada por ser apenas sintomática, deixando pendente a questão do sentido, por se interessar mais pelos sinais da doença do que por suas causas, concedendo à filosofia, à religião, a uma idéia da natureza humana, o encargo de responder a isso. Dado o declínio da filosofia e da religião nas representaçōes contemporâneas, este sentido é hoje procurado na ciência. Uma certa perda de credibilidade da medicina é contemporânea de uma nova reivindicação cultural do sentido. A medicina psicossomática (que busca nas desordens da psiquê a explicação última das desordens do corpo), a psicanálise (que faz do sentido o seu objeto) e, sobretudo, a medicina preventiva, por vocação, introduziram a questão do sentido e da causa no domínio da competência médica. É a partir da prevenção, isto é, de uma perspectiva causal, que o lugar ocupado pela medicina no campo social e no domínio das representações opera atualmente a sua mutação.

No entanto, a idéia de causa não engloba necessariamente a de sentido. Segundo B. Saint-Sernin ${ }^{22}$, "a noção de causalidade pode ser encarada de dois pontos de vista radicalmente diferentes: ou se supõe que nossa razão chegue diretamente à realidade em si - e então a palavra causalidade indica uma tentativa para se conhecer na verdade o ser e a razão de ser das coisas - ou então se supõe que o termo causalidade não denote uma propriedade das coisas, mas um modo de explicação, particularmente importante aliás, dos fatos que experimentamos. No primeiro caso, o ponto de apoio é um postulado metafísico: a razão humana pode perceber o ser e a razão de ser das coisas. No segundo, nos mostramos ao mesmo tempo mais modestos e mais críticos: considerando que o conhecimento começa com a experiência, definimos a causalidade como um modo de organizar sistematicamente os fatos empíricos e lhes dar sentido. Não se faz, por conseguinte, da causalidade uma categoria ontológica, mas conceito epistemológico, isto é, uma noção cujo sentido não é analisado à luz dos seus usos metafísicos, mas sim de sua aceitação nas ciências".

O ponto de vista positivista adota a concepção imodesta e ontológica; afirmar que o processo científico pode prescindir da perspectiva ontológica da causalidade é renunciar a levar em conta o sentido, ou seja, colocar em outro ponto a questão do sentido. O que não é feito pelo raciocínio comtiano, fundador do positivismo,

22. REGNIER A., La crise du langage scientifique, op. cit. 
sobretudo em sociologia. Negando a metafísica, ele a reintroduz em uma metafísica da eficiência científica.

Como diz W. Riese ${ }^{23}$, analisando a causalidade em medicina, o princípio de causalidade é primeiramente um princípio de representação do mundo. É o principio organizador da experiência, que lhe deve seu caráter sistemático e racional. É também um princípio de representação do mundo, de organização de suas representações. É uma representação de um mundo a ser dominado. "É-me impossível, talvez mesmo intolerável, fazer uma contabilidade dupla de meu orçamento intelectual e interpretar certos fenômenos por via causal, excluindo os outros. Não vejo como, por um tal processo, chegar a uma orientação segura e firme do meu espírito no seio de um mundo que recusaria meu domínio em princípio, domínio cuja fraqueza traria necessariamente o desmoronamento do lugar ocupado, graças aos seus esforços, pelo homem neste mesmo mundo."

Este mito moderno de Prometeu é relativamente recente. Nas filosofias antigas, o termo causalidade tinha uma significação bem mais geral do que tem hoje. Aristóteles distinguia quatro formas de causa: a causa formalis, que hoje se chamaria a estrutura ou o conteúdo conceitual de uma coisa, a causa materialis, isto é, a matéria da qual é feita uma coisa, a causa finalis, que é o objetivo de uma coisa e, enfim, a causa efficiens. Somente esta última corresponde mais ou menos ao que nós designamos hoje pelo termo causa. "Na medida em que o processo material ganhava em realidade, o termo 'causa' se aplicava ao processo material particular que precedia o acontecimento a ser explicado e, de uma certa maneira, o provocava. É assim que a fórmula da causalidade foi limitada e identificou-se finalmente ao fato de esperar-se que um acontecimento da natureza seja rigorosamente determinado e que, por conseguinte, o conhecimento exato da natureza ou de uma de suas partes seja suficiente, pelo menos em princípio, para prever o futuro."24

A medicina, querendo consolidar o seu status científico e ultrapassar a arte médica, devia renunciar ao sentido ou fazer dele o centro de sua posição científica, recentemente adquirida na ideologia dominante graças à biologia humana. Tendo optado por considerar o sentido, ela fez seu o processo positivista que confere à causa uma ontologia. É quando a medicina consegue operar a unificação de seu ponto de vista filosófico fundador sob a égide da ciência e do positivismo, ao mesmo tempo no seu campo tradicional de intervenção (a medicina curativa) e nos novos campos (medicina preventiva), que se pode falar de medicalização da sociedade. A continuidade estava estabelecida entre teleonomia da espécie (em

23. RIESE W., La pensée causale en médecine, P.U.F., 1950.

24. HEISENBERG W., La nature dans la Physique contemporaine, Gallimard, Idées, Paris, 1962. 
biologia humana), ontologia vitalista (quando esta nega o doente para só falar da doença) e todas as normas definidas pelas ciências sociais e epidemiológicas. A generalização possível, sob o ponto de vista positivista, das diferentes ciências do homem e de tudo que vive, quando confere a estas um denominador comum através de sua relação idêntica ao objeto (relação de eficiência e de instrumentalidade submetida à instrumen-talização econômica nas práticas gestionárias em termos de custo/eficácia), permite-lhes então intervir como instância unificada e particular. É a partir daí, aliás, que se abre a vasta perspectiva de interdisciplinaridade científica. O termo medicalização é contudo restritivo, na medida em que o ponto de vista descrito é adotado ao mesmo tempo e separadamente por cada uma das disciplinas em questão: medicina, epidemiologia, sociologia, economia médica, psiquiatria. Nos seus próprios esquemas de análise, cada especialidade pode utilizar como parâmetros os resultados da especialidade vizinha. A medicalização do social é acompanhada por uma penetração das ciências do homem no campo médico, normalmente de igual importância por suas conseqüências. A medicina e as ciências das quais ela procede, nem mais nem menos do que as outras disciplinas que se interessam pelo homem, têm o monopólio da resposta - quanto ao sentido - à questão das origens e do vir-a-ser. A biologia, a sociologia e a psicanálise, por exemplo, têm sua própria teoria da reprodução e da causa primeira. Cada uma está apta, no seu próprio campo, a nos explicar os determinismos que nos fazem ser, agir e vir-a-ser.

Por sua concepção ontológica de causa, a idéia moderna e dominante do determinismo tem a especificidade de pretender dar o sentido das coisas. Por conseguinte, ela institui a regra. Sendo aplicada ao objeto sentido em todos os campos cobertos pelas ciências do homem e do ser vivo, ela funda a norma constitutiva da lei que rege todas as situações da existência, os comportamentos, as relações entre os homens, e que governa os estados da pessoa e de seu corpo.

No interesse atual da sociologia da saúde pela etnologia, ciência que nos descreve as sociedades nas quais a doença está diretamente ligada a uma transgressão social ou moral, ver-se-á uma ilustração do fato de que, através do fenômeno recente da 'medicalização' do social, estão em jogo os valores centrais da nossa sociedade e a regulamentação em geral das relações sociais. Mais especificamente, as ciências do homem e do ser vivo tornaram-se partes fundamentais nas instâncias de elaboração da lei e de enunciação dos valores. Estas ciências, definindo as leis do normal relativamente aos estados do corpo e às relações sociais, contribuíram para transformar a noção de doença, ao mesmo tempo em que a faziam explodir, dando-lhe uma conotação de desvio. Com relação à regra, à ordem das coisas e dos seres humanos, a doença, na sua representação dominante, tornou-se uma das catcgorias da subversão. 
É a hipótese que nós tentaremos defender na continuação deste artigo, a partir de uma análise da evolução dos fundamentos da responsabilidade e da relação desta com o corpo. Mostraremos que o direito liberal definia um status duplo e 'dicotomizado' da responsabilidade. Um deles fundado sobre a propriedade, o outro sobre a dependência salarial. A noção de infração que valida a noção de responsabilidade tinha também aí um status duplo. Em um caso, a infração supunha um espaço de liberdade, no outro a infração era um estado consubstancial relativo à situação de dependência. A evolução da noção de responsabilidade é caracterizada pelo desaparecimento de seu fundamento, a infração, em proveito da causa. Neste sistema, as leis produzidas pelas ciências do homem e do ser vivo estão em situação de dar um conteúdo à noção de causa, introduzindo uma nova concepção da infração. Esta concepção procede da filosofia do sentido e da história dominante nessas ciências.

\section{Os fundamentos da responsabilidade: o duplo status do direito liberal}

O direito burguês pós-revolucionário instaurou uma ligação necessária entre o dever moral e o poder material. "A liberdade supunha a existência de uma coisa material, de uma fortuna que sancionava, após tê-la verificado, a autonomia da pessoa. O exercício do direito de propriedade era a medida do grau de liberdade do qual se dispunha. A liberdade era uma liberdade de proprietário. Nessas condições, a vagabundagem era um delito, pois o vagabundo não possuía nada que the permitisse afirmar, medir e limitar simultaneamente sua liberdade." ${ }^{25}$

Segundo R. Savatier ${ }^{26}$, a Revolução Francesa tinha prolongado, por um patrimônio incorpóreo, sua concepção de propriedade enquanto liberdade ampliada da pessoa. Os decretos de janeiro de 1791 e de julho de 1793 tinham inaugurado, para as obras do espírito, a propriedade literária e artística. Sob a propriedade, era a pessoa que o direito então descobria. No direito, conseqüentemente, a noção de pessoa era inseparável da propriedade material, literária ou artística. Desde então, os atributos e os direitos da pessoa ampliaram-se consideravelmente sob o ponto de vista jurídico. Isto só pôde acontecer por eles terem sido separados da propriedade. Os atributos da pessoa no seu trabalho assalariado foram definidos. Com a extensão do salariado, a contratação de serviços saiu do Código Civil para se tornar o contrato de trabalho regido por um novo direito, o direito do trabalho.

25. LEVY T., Le désir de punir. Essai sur le privilège pénal. Fayard, 1979.

26. SAVATIER R., Les métamorphoses économiques et sociales du Droit privé d'aujourd 'hui, $3^{\mathbf{2}}$ serie, Approfondissement d un Droit renouvelé, Dalloz, 1959. 
Até a década de 1960 , a tradição do direito civil, diz R. Savatier ${ }^{27}$, não considerava a saúde como fazendo parte dos atributos jurídicos do estado da pessoa, ou só a incluía muito parcialmente. Para este autor, a própria extensão dos atributos e direitos da pessoa é inseparável dos perigos que nossa civilização inflige à pessoas: "Por causa das ameaças com as quais a civilização contemporânea cerca por todos os lados a pessoa, os juristas, intérpretes de uma necessidade primordial e instintiva da humanidade, foram levados a reconhecer e a salvaguardar os direitos do homem, no seio desta civilização material, por conseguinte hostil à pessoa. Seu esforço de promoção é, em sentido amplo, uma reação de defesa."

Quanto a estas constatações, podemos fazer várias observações. O poder material exercido sobre a coisa, adquirida ou produzida, e os deveres que a ela são ligados (o dever do bom proprietário e do bom pai de família) são sem dúvida a expressão da autonomia da vontade, já que este poder é garantido pela propriedade. Do mesmo modo, no trabalho livre da pessoa, encontra-se a propriedade literária e artística. Por outro lado, o trabalho 'livre' do assalariado instaura um corte radical entre a coisa material produzida e o poder da pessoa, entre o princípio da autonomia da vontade e o seu exercício. De fato, a contratação de serviços saiu do Código Civil para ser regida por um direito particular que responde a outras situações econômicas e a outros princípios jurídicos que não as situações e princípios que subentendem o Código Civil. O produto do trabalho 'livre' não é mais a expressão da vontade autônoma da pessoa, a manifestação de seu poder, mas a de uma situação de dependência: a dependencia que, pelo contrato de trabalho, liga o assalariado ao patrão e o transforma em mercadoria. Os direitos ligados ao contrato de trabalho definem bem os atributos da pessoa, mas de uma pessoa cujo status jurídico é distinto do status da pessoa que era descoberta pelo direito de propriedade. São direitos que, antes de mais nada, consagram sua dependência econômica e jurídica e que organizam em seguida sua defesa diante dos possiveis abusos do poder patronal.

O direito à saúde oriundo do contrato de trabalho pertence a esta concepção defensiva e dependente, quer se trate dos direitos da saúde no trabalho (poder de seleção do patrão, proteção do trabalhador) ou fora dele: proteção dos indivíduos diante dos possíveis abusos de poder do corpo médico (a existência da declaração dos direitos do doente por exemplo) ou do poder regulamentar (ver o debate em torno do sistema G.A.M.I.N.). Os direitos do trabalho e o direito à saúde aparecem então como direitos públicos e privados de garantia, ligados à dicotomização dos direitos da pessoa.

27. SAVATIEK R., op. cit. 
A contradição, percebida por R. Savatier, entre um direito material da pessoa sobre a coisa e o exercício social deste direito hostil à pessoa caracteriza o status duplo do direito liberal. Em nome de um direito objetivo da pessoa, firmando-se como um dos grandes princípios gerais do direito e dos direitos do homem, como a liberdade e a igualdade, são garantidos os direitos subjetivos opostos: isto é, a manutenção das situações econômicas e sociais desiguais pelo dispositivo de conjunto das leis positivas.

Para os teóricos marxistas do direito, o caráter jurídico da regulamentação das relações sociais é somente a forma de que se revestem historicamente as diferentes relações na sociedade de produção mercantil liberal. A relação jurídica entre os sujeitos pressupõe uma economia atomizada. $O$ vínculo jurídico é mantido pelos contratos concluídos entre as diferentes unidades econômicas privadas e isoladas. "A relação jurídica entre os sujeitos é apenas o inverso da relação entre os produtos do trabalho tornados mercadoria." ${ }^{28} \mathrm{~A}$ derrubada do sistema capitalista deve trazer consigo a supressão do direito. Se esta análise parece fundamentada no nível econômico onde se situa, não nos parece justo que por isso se reduza o direito à sua dimensão econômica. Esta redução traz com ela uma identificação do direito com o seu componente subjetivo. O direito é concebido a partir das noções de interesse de conservação. Ora, noções como igualdade e liberdade são mais amplas do que elas. Através do componente objetivo do direito, é a possibilidade mesmo de existência do político e da crítica que se afirma. Aliás, a dimensão objetiva do direito é inseparável de sua função simbólica: a idéia do direito objetivo, independentemente dos interesses privados garantidos pelo direito positivo, funciona como referência universal, baseado na proclamação de um direito natural. Em seu nome, liberdades mais amplas e uma igualdade não mais apenas formal podem ser e foram reivindicadas. A igualdade natural e revelada pelo direito objetivo abre a possibilidade da garantia (de princípio), pela lei única, dos direitos positivos correspondentes.

A extensão do salariado e a passagem ao estágio monopolista do capitalismo tiveram por efeito modificar consideravelmente o direito positivo. Esta evolução se caracteriza pelo declínio da autonomia da vontade, pela explosão da noção de contrato, pelo desaparecimento da responsabilidade baseada na infração, fundamento do direito civil pós-revolucionário e, ao mesmo tempo, pela extensão das obrigações de seguridade, da socialização obrigatória dos riscos. E, sobretudo, aparecem 'privilégios', que antigamente eram parte integrante e evidente do direito

28. PASUKANIS E.B., La théorie générale du Droit et le marxisme. E.D.I., 1970. 
privado e que agora conseguem se impor cada vez mais, pelo desenvolvimento da economia dirigida (por exemplo, nos bancos ou nas empresas de transporte), ou através do desenvolvimento das instituições sociais (por exemplo, nas casas de saúde ou nas agências de notícias) e até no jogo da função pública. Estes privilégios são, por outro lado, cada vez mais atributos de sociedades civis ou comerciais ao invés de pessoas físicas, efeito de uma socialização elementar que despersonaliza, no sentido profundo do termo, os indivíduos.

J.Habermas ${ }^{29}$ descreve assim esta transfor-mação: a evolução da sociedade capitalista e a aparição do fenômeno do feudalismo industrial têm por efeito substituir, por garantias públicas, toda uma série de funções ligadas ao poder discrionário privado. Mas, no quadro mais estreito destes direitos e obrigações sócio-políticas, o fenômeno primordial, que a perda de um poder discricionário constitui, tem por efeito secundário transformar esta perda em uma descarga de responsabilidade de caráter público. Já que os cidadãos não têm mais a possibilidade de fundamentar a autonomia de sua vida familiar - nem no fato de dispor de uma propriedade privada, nem em uma participação na esfera pública - a individuação da pessoa segundo o modelo da ética protestante não pode mais ser garantida pelas instituições. O autor afirma que, enquanto o Estado obedecia ao modelo liberal, a esfera das trocas e do trabalho social - e isto correspondia aos interesses da burguesia - ficava nas mãos da autonomia privada. A evolução da sociedade capitalista modificou, limitando-a, a esfera privada.

O que caracteriza então a época liberal do capitalismo, do ponto de vista do status da pessoa, é uma autonomia da vontade que se exerce a partir de um espaço de poder e de liberdade fundamentado na propriedade privada. Esta propriedade garante o espaço privado da pessoa. A autonomia jurídica tem o seu equivalente na esfera intelectual e moral. "Os filósofos da Revolução Francesa", lembra G. Gurvitch $^{30}$, "afirmaram a confiança de que o homem pode lançar mão de sua consciência e de sua razão para regulamentar ele mesmo o destino da humanidade: tal é a base de sua descoberta da ética moderna da ordem moral e jurídica, essencialmente independente de todas as outras ordens, e afirmando-se em sua especificidade própria. Eles afirmam o princípio da equivalência de toda pessoa humana, sem exceção, reconhecida na sua dignidade moral, como um valor em si (...); a idéia da liberdade criadora e espontânea que não teconhece nenhuma ordem predeterminada anteriormente e imposta do exterior; a idéia da soberania do direito

29. HABERMAS J., L'espace public, archéologie de la publicité comme dimension constitutive de la société bourgeoise, Payot, Paris, 1978.

30. GURVITCH G., L'idee du Droit social, Sirey, Paris, 1932. 
diante do qual deve curvar-se qualquer espécie de poder." A idéia de direito objetivo e natural era associada à de razão objetiva e revelada. As regras consideradas como universais garantiam a individuação; objetivas, elas permitiam o desenvolvimento da subjetividade; abstratas, eram garantias do mundo concreto. ${ }^{31}$ E. Durkheim, no mesmo sentido, garantiu que o racionalismo não era mais do que um dos aspectos do individualismo, que era o seu aspecto intelectual.

Esta autonomia, concreta para os que gozaivam da propriedade no plano econômico e familiar, abstrata e objetiva no nível das representações do Direito, da Razão e da Moral, tinha sua equivalência no nível do corpo. A pessoa era o seu corpo, dotado de uma vitalidade autônoma que achava em sua criatividade sua norma de funcionamento.

\section{O status duplo da infração em matéria de responsabilidade}

A responsabilidade individual era, no direito liberal, baseada na infração. A infração supunha, para sua imputação, esta autonomia e esta liberdade que encontravam para exercer-se uma natureza humananão predeterminada, comohoje tornou-se a pessoa.

Mas a liberdade, nos diz T. Levy ${ }^{32}$, ligada à propriedade, tinha como limite o corpo, único inimigo da liberdade. É assim que ele dá conta, até 1867, da repressão pelo corpo, isto é, a prisão por dívida, assim como a existência do delito de vagabundagem. O que a lei diz ao vagabundo é que a pessoa física, em si mesma, não saberia constituir sua autonomia civil e social. Por outro lado, ela é suficiente para constituir sua autonomia moral e penal. $\mathrm{O}$ direito, isto poderá ser verificado aqui, não se confunde com a lei: na ausência de um bem material que defina a autonomia concreta da pessoa pelo bom e mau uso que ela faz desta autonomia dentro de um quadro de direito concreto (o direito civil), a tutela direta do Estado se exerce considerando que o indivíduo disponha de seu corpo para exercer a liberdade. Dispondo de bens, os sujeitos podem trocá-los entre si, por contrato, sem intervenção do Estado (ou então tê-lo como terceiro fiador e simbólico) e engajar aí sua responsabilidade. Os outros sujeitos só têm sua moral e seu corpo para engajar, seja no quadro do direito penal, como o vagabundo, seja no quadro do direito social mais amplo.

Resulta disso que a infração reveste uma natureza dupla, à luz da liberdade e da responsabilidade: em certos casos ela supõe a liberdade, quando se dispõe

31. HABERMAS J., L'espace public, archéologie de la publicité comme dimension constitutive de la société bourgeoise, op. cit., 1978.

32. LEVY Th., Le désir de punir. Essai sur le privilège pénal. Fayard, 1979. 
de bens, em outros é original ou consubstancial, quando qualifica um estado como a vagabundagem. Pode-se assim engajar a liberdade sem que haja meios de exercê-la.

\section{Da responsabilidade à garantia}

Hoje, o status da responsabilidade modificou-se e, ao mesmo tempo, modificaram-se os do corpo e da infração. Em direito, a substituição de um sistema de seguros generalizados para üma responsabilidade baseada na infração faz repousar a responsabilidade sobre a causa que se vai assegurar. A idéia de causalidade é assim substituída pela idéia de imputabilidde como uma espécie de sinônimo. A passagem de um sistema de responsabilidade jurídica individual baseada na infração a um sistema de responsabilidade sem infração, baseado em um direito coletivo de garantia, tem por efeito fazer frente à regra de base da autonomia civil da vontade. Pela autonomia civil são substituídas a obrigação de segurança e de proteção social; deve-se lembrar, insiste R. Savatier, que o advento universal de uma legislação de seguridade social integra-se ao risco profissional, obrigatoriamente assegurado pelo patrão. Questionar o advento e a extensão da Seguridade Social exigiria então que este fenômeno fosse restituído ao seio do sistema de segurança como fato social, que se procurasse em quê os conceitos de garantia, de risco, de insegurança ( $e$ as necessidades que dela derivam), assim como o conceito de proteção social, substituíram os de autonomia e de infração, de liberdade e de responsabilidade. Que sentido têm estas transformações à luz das relações sociais e de suas representações? É sobretudo o segundo ponto que constitui aqui o objeto de nosso questionamento.

\section{Da causa jurídica à causa científica}

A análise do status da noção de causa deve permitir que apreendamos o caráter dependente do direito e da ciência, na medida em que é precisamente através da noção de causa que se passa do direito à ciência enquanto instância de definição da lei da relação social com a pessoa e o seu corpo. $\mathrm{O}$ abandono de um sistema de responsabilidade baseado na infração que privilegia um sistema fundamentado na causa constitui, nesse aspecto, a indicação de vários níveis de transformação:

1) A responsabilidade baseada no poder material definia um certo campo de liberdade. Sucede-lhe uma ordem prescritiva em um quadro de dependência. A noção de infração civil implicava o uso da liberdade, a noção de causa descobre determinismos.

2) A causa é também a coisa, isto é, a objetivação de si como meio de trabalho e coisa a ser assegurada. 
3) A causa é enfim uma maneira de acusar: "O enunciado da lei científica é escrito por homens, o que faz com que sua colocação traga a discussão. Deve-se notar que a palavra grega alria significa indistintamente infração e causa". ${ }^{33}$ Tratase de uma visão pessimista da natureza humana que ela subentende. Ohomem deve se defender de si próprio, exercendo sua responsabilidade e submetendo-se às normas definidas pelas ciências do homem e ao poder dos que as aplicam. Sua responsabilidade é medida pelo seu esforço de adaptação a uma situação dependente, garantida pela ordem científica.

Quais os riscos assegurados pelo patrão? Tanto os riscos econômicos, que ele assume, quanto os riscos que ele inflige aos seus empregados durante o trabalho. A pessoa do empregado como meio de trabalho tem o mesmo status dos bens assegurados e do risco econômico. Este sistema de garantia em dois níveis - o risco econômico do patrão e o risco corrido pelo empregado, sua pessoa física sendo aí incluída - reforça e institui um sistema de dependência em cadeia, que vai até o Estado (ele é o último a garantir este sistema de dependência), tendo por base o salariado, fazendo com que o risco corrido pelo empregado através de sua produção de mais-valia seja a garantia do lucro de seu empregador.

A medicina e as diferentes instituições que tratam do assunto participam deste sistema de garantia, assegurando o bom estado da máquina. No domínio do trabalho, a medicina ajusta o alor do indivíduo no mercado às suas capacidades produtivas e o autentifica. A relação médico-doente, efetuada no quadro da esfera privada e contratual, correspondia a uma demanda privada computável quando havia renda suficiente. Hoje, com as medicinas preventivas, a demanda tornou-se social. A prevenção, em seus diferentes desenvolvimentos, concorre para a edificação das garantias públicas do status do trabalhador como meio de trabalho, e do status familiar, concedendo à família apenas uma autonomia dirigida.

\section{A separação do corpo}

Com a responsabilidade, a pessoa e o corpo mudaram de status jurídico. As máquinas vivas tornam-se mais concessões duráveis, cujo título é protegido pelo poder público, do que bens. "A liberdade perdeu seu valor jurídico. Diversos e móveis, os direitos sociais substituíram as obrigações que elas haviam criado." 34 O corpo, bem material por excelência, separa-se da pessoa para se tornar um atributo. É o que sublinha A. David: "O ano 1967, ano do primeiro transplante de

33. KOJEVE A., Esquisse d'une phénoménologie du droit, Gallimard, Paris, 1981.

34. LEVY Th., Le desir de punir. Essai sur le privilege pénal. Fayard, 1979. 
coração, foi sem dúvida uma data importante: a da separação com o corpo." ${ }^{35} \mathrm{O}$ corpo não pertence mais à pessoa: a pessoa não é um corpo, ela tem um corpo, dado a ela, intercambiável e uma riqueza, que pode ser dada e transplantada, é simulável e se torna uma vestimenta preciosa, porém anônima. Esta vestimenta tomou sua verdadeira quantidade, pois compreende a quase totalidade do pensamento e, em suma, todo o pensamento executivo. A informação e os autômatos fizeram cair retumbantemente o pensamento executivo na matéria estranha e cambiável. O contrato de trabalho, o contrato de empresa, o contrato de edição organizam alienações provisórias ou definitivas de energia e de informação contidas no corpo vivo e também locações sem deslocamento e em tempo dividido da matéria viva do corpo. Mas há pouco tempo a cessão de órgãos vivos (transplante) e "a aparição de órgãos artificiais trouxeram a prova plausível do caráter anônimo e intercambiável dos órgãos vivos, elementos de um patrimônio que se desloca e gira em torno de pessoas imóveis e indivisíveis". ${ }^{36}$ Mais recentemente, a lei de 12 de dezembro de 1976, relativa à coleta de órgãos, trouxe uma inovação fundamental. Presumese que - e se trata de presunção irrecusável - que doravante os vivos podem consentir que sejam retirados órgãos de seu corpo após sua morte. "O corpo anônimo e intercambiável, estranho à pessoa, afastou-se desta, enquanto as máquinas, ao contrário, aproximaram-se do corpo. Elas prolongam, substituem e eliminam este corpo bem amado, oferecendo os mesmos serviços, passageiros e imperfeitos." ${ }^{37}$ Esta identidade do homem e das coisas foi percebida por W. Heisenberg. ${ }^{38}$ "No futuro, os numerosos aparelhos técnicos serão talvez tão inseparáveis do homem quanto a casaca do caramujo ou a teia da aranha. Mas, mesmo neste caso, estes aparelhos seriam parte do organismo humano, mais do que partes da natureza à sua volta".

Este distanciamento da pessoa em relação a seu corpo corresponde à perda de poder discricionário privado que se estenderia ao corpo e à sua assimilação à coisa protegida. $\mathrm{O}$ declínio da autonomia da vontade em proveito de uma socialização legal garantida pelo Estado instaura um sistema tutelar em relação ao que é protegido, segurado. Assim acontece com o corpo. Sob este ponto de vista, o ser transforma-se em ser pertencido.

35. DAVID A., Matière, machines, personnes, Bordas, Etudes 3, Philosophie des Sciences, 1973, p. 11.

36. DAVID A., Matière, machines, personnes, op. cit.

37. DAVID A., Matière, machines, personnes, op. cit.

38. HEISENBERG W., La nature dans la Physique contemporaine, Gallimard, Idées, Paris, 1962. 
A passagem da autonomia à tutela estatal como distanciamento de si para com o corpo traduziu-se, como se viu, na evolução do direito; é concomitante ao desenvolvimento dos seguros e foi favorecido pela extensão do ponto de vista positivista. Objetivando o que analisa, o positivismo instaura este distanciamento que confere ao objeto o status de coisa. Pode-se dizer que as categorias positivistas dão ao seu objeto de conhecimento o status que as mercadorias têm, no nível da produção de bens. O positivismo utilizado pelas ciências do homem é o equivalente e a extensão, no nível da gestão de recursos humanos, do que são as mercadorias no nível da produção, segundo as mesmas regras de expropriação e de separação entre o homem e seu produto. É a extensão ao corpo, às diversas atividades e aptidões mentais, físicas e sociais, da relação social capitalista - relação que se aplica ao homem considerado como uma mercadoria. O positivismo se tornou um instrumento privilegiado de gestão do social, sendo este último por sua vez isolado como objeto.

O encontro entre as ciências do homem e as seguranças acontece, assim, no momento de uma apreensão comum dohomem. A objetivação do corpo e da pessoa do indivíduo através dos sistemas de segurança, sua redução à 'causa-coisa', encontram este tipo de objetivação, operado pelas ciências do homem, funcionando em um esquema normativo e causalista. Estas ciências participam diretamente da extensão da tutela estatal, substituindo o direito civil na definição das normas positivas e das necessidades; a necessidade geradora da norma tomou o lugar da autonomia no exercício do direito civil. Elas estabelecem as normas e as necessidades em uma variedade infinita e quase exaustiva (por vocação) de áreas de existência. Prescrevem o que deve existir em matéria de relações humanas, de adaptação ao trabalho, de sexualidade, de pedagogia, de saúde etc. O intervencionismo científico, isto é, a imposição da lei positiva às condutas da existência, torna suspeitos a autonomia da vontade e o senso comum. As tutelas profissionais, científicas e administrativas são necessárias ao indivíduo para regulamentar sua conduta. Assim, as 'normas de vida', os 'estilos de vida' opostos à saúde e ao desvio são palavras chaves em torno das quais se organiza o processo de socialização e de tutelamento, que anteriormente tinha a ver com a esfera privada. Estas normas se distinguem essencialmente do direito liberal, que substituem, no seguinte: este direito, construído sobre o princípio da autonomia da vontade, era, na sua concepção, um direito mínimo enegativamente definido, que preservava assim um espaço de liberdade da pessoa. Liberdade essencialmente renegada pelo normativismo das ciências do homem.

Esta negação da liberdade em proveito do determinismo propõe uma representação pessimista da natureza humana, não muito diferente da de São Tomás de Aquino ou de Lutero, segundo os que is a queda enfraqueceu consideravelmente, 
senão corrompeu completamente, a natureza humana. Estas representações fundamentam a função do Estado (ordenar o estado de pecado) e justificam o Estado com autoridade. Poena et remedium peccati, tal era o privilégio do Estado. ${ }^{39}$

Hoje, o destino social, psíquico e biológico do indivíduo é 'coisificado' e atado a uma história social, psíquica e genética, uma história que não lhe pertence e que lhe deixa um sentimento de culpabilidade consubstancial. A sua única infração é existir, como o vagabundo, em um estado desviante por natureza, frente à norma social, corporal ou psíquica. Sua única responsabilidade, ou sua única liberdade, é prescritiva: consiste na busca aleatória de uma boa saúde, de um eu que não se pertence e de uma boa adaptação profissional e social.

É neste sentido que F. Basaglia disse que o individuo vive sua inserção no mundo enquanto doente. "E através deste processo de racionalização $e$ de organização das necessidades que o individuo está privado da possibilidade de pertencer a si mesmo (sua própria realidade, seu próprio corpo...). Neste sentido, o fato de pertencer-se transforma automaticamente em ser pertencido, já que não se trata nem mesmo da superação de uma contradição, mas da racionalização em termos de produção, da qual ele é o objeto. Nesta dinâmica, o indivíduo não pode chegar à posse de sua própria doença, mas vive sua inserção no mundo enquanto doente; ele vive, assim, o papel passivo que lhe é conferido e que confirma a fratura entre ele e sua própria pessoa" ${ }^{40} \mathrm{~A}$ isso, acrescentaremos que, ao mesmo tempo, o indivíduo vive sua inserção no mundo enquanto desviante, no sentido de que a fonte de normalidade e das necessidades está situada fora do campo de competência do médico, e enquanto doente, no sentido de que esta normatividade produz a necessidade de ntervenção e de prótese social, cuja necessidade terapêutica constitui o modelo. R. Sennett ${ }^{41}$ analisando o declínio do espaço público, chega a constatações da mesma ordem. Ele mostra que uma sociedade cuja lógica consiste em absorver pessoas e questões que dizem respeito à adequação de si próprio, no trabalho e em outras relações de desigualdade, está estruturada através de uma imagem explodida do eu em dois; entre o 'eu' e o 'mim', em um espelho que nunca reflete algo fixo. O verdadeiro eu é aquele dos impulsos e das motivações, é o eu ativo; mas o eu em sociedade é passivo. Ele conclui que o narcisismo é a ética protestante dos tempos modernos... "Os indivíduos procuram-se continua-

39. BLOCH E., Droit naturel et dignité humaine, Payot, Paris, 1976.

40. BASAGLIA F. e ONGARO F., La majorité déviante, Paris, 1976.

41. SENNET R., The Fall of Public Man, Knopf, New York, 1977. 
mente, tentam achar um sentido para sua existência em uma realidade que não admite nenhum limite para o eu."

A separação entre a pessoa e seu corpo, a objetivação desteúltimo, seu destino como caução viva da empresa, constroem uma imagem da natureza humana enquantonatureza doentia. Elas contribuem para desenvolver uma ética terapêutica fundamentada na proteção do indivíduo em relação a si mesmo. O seguro obrigatório o garante contra si próprio. $\mathrm{O}$ fantasma coletivo da insegurança, que caracteriza hoje a imagem da relação com o outro, aparece como uma projeção da incerteza de cada um frente a si mesmo, da atitude de defesa de cada um em relação à sua pessoa, de sua situação histórica como ser irresponsável e dependente, de seu estado consubstancialmente doentio.

\section{III - A ORDEM PENAL-CIENTÍFICA}

Se o Direito pode ser definido pelo conjunto das leis positivas que o constituem, ele detém igualmente uma função simbólica, oriunda da idéia de sua origem convencional e consensual. Esta função se realiza sobretudo na idéia de direito natural que o acompanha, particularmente na de um direito natural igualitário. Se todos os homens são livres por sua própria natureza, nenhum é superior ao outro. Logo, por sua própria natureza, todos os homens são iguais entre si. O direito natural implica a salvaguarda ou restauração da liberdade ou da igualdade naturais. Oúnico caminho possível para a sociedade civil, quando ela quer conciliar-se com a liberdade e a igualdade naturais, passa pelo consentimento ou, mais precisamente, pelo contrato que liga indivíduos livres e iguais. ${ }^{42}$ Daí procede o universalismo da lei.

A comunidade de pensamento do Século das Luzes com o pensamento grego reside nessa afirmação do direito natural igualitário. Este pensamento opõe ao costume, à autoridade da tradição, a opinião arbitrária do indivíduo, isto é, o seu livre arbítrio e o conceito de natureza enquanto conceito natural de valor. Essencialmente individualista, o direito natural se define de modo mais estreito do que o direito positivo, e de maneira negativa. Seu único valor é impedir os danos recíprocos. Os direitos concretos se desenvolvem na liberdade permitida por um Estado mínimo, à margem dos contratos concluídos entre indivíduos livres $\mathrm{e}$ iguais. $\mathrm{O}$ direito é essencialmente privado. ${ }^{43}$

42. ZEMPLENI A., Mal de soi, mal de l'autre, op.cit.

43. O conjunto do direito burguês francês foi construído em torno do direito civil e dos grandes princípios juridicos que o fundamentam. 
Segundo A. Kojeve ${ }^{44}$, a função do Estado em relação ao direito, cuja essência é ser privado, é de intervir como um terceiro imparcial e desinteressado, encarnando a sociedade. O direito público e o direito penal, na medida em que este último pertence ao direito público, estão fora do direito. "Onde há um direito, não há direito público no sentido constitucional. A lei constitucional que fixa a estrutura do Estado propriamente dito nada tem a ver com uma lei jurídica. Ou ainda: as relações do Estado consigo mesmo estão fora do domínio do direito e mesmo da justiça. Se a lei constitucional diz respeito ao próprio Estado, se ela é considerada como uma lei que regulamenta a estrutura do Estado enquanto tal, ela com certeza não é um direito, pois não deixa nenhum espaço para a existência de um terceiro." Do mesmo modo, para ligar seres livres e iguais, não há obrigação jurídica possível entre o senhor e os indivíduos submetidos ao seu poder. A relação salarial, nessas condições, escapa à obrigação jurídica.

A afirmação do direito natural contém implicitamente a idéia do estatuto objetivo da razão. É a idéia das noções comuns da doutrina estóica: "Aquelas que, graças à natureza de nosso pensamento, são deduzidas igualmente por todos da experiência. Elas fundamentam o acordo essencial de todos os homens, o consensus gentium do direito natural ulterior, e contêm a mais certa das verdades. Fazem do direito natural uma evidência para todos". ${ }^{45} \mathrm{O}$ estatuto objetivo da razão está na origem da afirmação do direito de crítica e de suas possibilidades de expressão. J. Habermas mostrará que este uso público e comum do raciocínio permitirá à esfera pública burguesa constituir-se contra o poder do rei.

Hoje, a lei substituiu o direito tal como foi definido acima, e o direito social desenvolveu-se em detrimento dos direitos público e privado; o raciocínio desertou a cena pública, seguindo um processo de socialização e de estatização.

Uma esfera social nasceu, limitando os espaços públicos e privados que ela absorvia. A idéia de direito natural, aliás combatida tão logo difundida, negada pelas relações de força econômicas, deu lugar, nas representações dominantes, ao 'historicismo'46, do qual o positivismo é a forma mais moderna. As situações de direito criadas pelos contratos foram substituídas por direitos sociais publicamente garantidos; os direitos universais foram sucedidos por um direito cada vez mais

44. KOJEVE W., La nature dans la Physique contemporaine, Gallimard, Paris, 1981.

45. GURVITCH G., Eléments de sociologie juridique, Aubier, Paris, 1940.

46. O historicismo, no sentido em que o emprega L. Strauss, é uma forma particular do positivismo, filosofia que nega a metafísica, a ética filosófica e o direito natural, que nega igualmente a possibilidade de uma objetividade histórica. 
amplamente estatutário - mudanças que, in fine, comprometem as idéias de igualdade e de liberdade (no sentido de que esta carrega em si os Direitos do Homem).

J. Habermas descreve um processo duplo que tende a uma polarização progressiva da esfera social e da esfera privada, em proveito de um poder de classe quase público. "O prolongamento da autoridade do Estado a domínios privados mais numerosos tem por corolário o processo inverso, segundo o qual o poder social substitui o Estado em certas ocorrências. A base da esfera pública burguesa só começa a se desmanchar a partir do momento em que se estabelece esta dialética de uma socialização do Estado e de uma estatização da sociedade, que se afirmam ao mesmo tempo. Podemos constatar, entre o Estado e a sociedade, a aparição de uma esfera social repolitizada que escapa à distinção entre o privado e o público. Ela dissolve também este domínio específico da esfera privada, no seio do qual as pessoas reunidas em um público regulamentavam entre si os assuntos gerais que tratavam de suas trocas, em outras palavras, a esfera pública sob sua forma liberal." ${ }^{47}$ Esta esfera é o produto da profissionalização da sociedade e da substituição do direito pela lei que este gerou, nesse duplo processo de estatização da sociedade e de socialização do Estado. A socialização do raciocínio foi acompanhada de uma apropriação, pelo Estado e por suas administrações, do conhecimento científico como fonte de normatividade positiva e instância de produção de leis com valor universal. Isto feito, as profissões que ocupam a esfera social (esfera sócio-sanitária e a da gestão social em geral) devem o seu importante e recente desenvolvimento ao papel, que lhes foi devolvido pelo Estado, de executantes da lei que elas contribuíram para enunciar.

A razão viu o seu estatuto transformado, após ter permitido, por seu uso público, a constituição de uma esfera pública crítica e a derrubada do poder real, por seu próprio uso no curso da edificação da era capitalista liberal e da superação desta com o desenvolvimento das técnicas e das ciências. Socializando-se, esse estatuto faz-se lei e instância jurídica, contribuindo assim para o prolongamento da autoridade do Estado a domínios privados mais numerosos.

Assim, as ciências do homem instituíram o direito como novo princípio de normatividade positiva, trabalhando principalmente para substituir o direito pela lei.

"O conjunto dos contratos se torna científico (...) Nenhuma economia dirigida funciona sem especialistas. É o aspecto mais coletivo da submissão dos

47. HABERMAS J., L'espace public, archéologie de la publicité comme dimension constitutive de la sociéte bourgeoise. Payot, Paris, 1978. 
contratos à ciência. Mas cada contrato em si já está submetido ao imperium desta". ${ }^{48}$ O mesmo acontece com o sistema probatório: as fases da convicção íntima e da prova legal são sucedidas pela da lei científica. Tanto no direito penal (através do recurso, como procedimento de prova, aos resultados de ciências anexas, como a psicopatologia clínica ou legal, a psicologia experimental e a lógica), quanto no Direito civil e comercial (através do recurso à perícia, ao raciocínio dedutivo $\mathrm{e}$ indutivo). ${ }^{49}$ Segundo J. Delatte ${ }^{50}$, novas formas de avaliação de responsabilidades por profissionais das ciências do homem se desenvolvem contra a corrente da instituição jurídica, sem substituí-la: elas se inscrevem em complementariedade com a instituição e definem suas próprias exigências ao seu respeito. A Justiça dos menores provém essencialmente das instituições que se atribuem o direito e a competência de cobrir o campo da prevenção e determinar suas normas de intervenção (serviços sociais, serviços médico-sociais e polícia dos menores).

Isto agora já é sabido o suficiente. Parece-nos necessário, no entanto, insistir sobre vários pontos.

1) A penetração do poder científico no domínio jurídico, que tem por efeito introduzir, ao lado do discurso da lei, o da norma, é acompanhada de um fenômeno da mesma importância social: sempre que as administrações responsáveis por avaliações sócio-sanitárias recorrem às ciências do homem fora do domínio jurídico, cria-se um poder quase jurisdicional, que se estende na medida da proliferação dos indicadores sociais e de todas as leis de funcionamento social, psicológico e biológico descobertas pelas ciências do homem. Estas leis, que definem as normas da esfera do que dependia anteriormente do Direito Civil e do Direito, no sentido em que o entende A. Kojeve, aparentam-se com o Direito Penal. Normativas, elas estão combinadas a um poder de sanção. Condição para a abertura de certos direitos, elas limitam as capacidades de gozo dos indivíduos.

A medicina pública, social e preventiva, exerce um papel sócio-penal quando limita o exercício de direitos a partir da prova da existência de certas doenças; a medicina está em posição jurisdicional quando aflige, com a incapacidade, os doentes que ela priva do direito de se empenhar em certas profissões, de aceitar certos trabalhos. Eliminando-os na entrada dessas profissões, procedendo a exames periódicos de saúde, prevendo que o contrato de trabalho será suspenso obrigatoriamente se certas doenças aparecerem, estabelecendo comissões de reforma para eliminar os profissionais doentes, criam-se incapacidades.

48. SAVATIER R., op. cit.

49. GORPHE A., L'appréciation des preuves en justice. Les décisions de justice. Sirey, 1952.

50. EVANS-PRITCHARD E.E., Sorcellerie, oracles et magie chez les Azandé, op. cit., pp.86-94. 
Isto é verdadeiro também para a medicina escolar (ver, por exemplo, o papel das comissões departamentais de educação especial). Da mesma forma, em sua alma e consciência, após observar a relação mãe-criança, a assistente social ou o médico de P.M.I. (Proteção Materno-Infantil), em função de normas que podem diferir de uma para o outro, decidirão se uma criança deve ou não ser separada de sua família. Quando não faz a lei, a medicina participa da normalização, como atesta a ofensiva da educação sanitária, particularmente através da P.M.I., com a constituição de grupos de mulheres grávidas ou de jovens mães. Aqui, a socialização sob tutela médica é um meio de aprendizado com duplo objetivo. Ele estimula novos comportamentos, desenvolvendo uma aptidão para a convivência dirigida. Certas correntes da medicina liberal, há pouco tempo atraídas por este movimento de rearmamento moral, querem se constituir em parte fundamental, participando da educação sanitária (ver as posições do Sindicato Nacional dos Médicos de Grupo sobre a questão).

A lei sócio penal tende então a dissolver a relação jurídica criadora de direito no sentido civilista privado, substituindo-as por uma relação de dependência tutelar difusa no seio da sociedade civil ${ }^{51}$, relação de dependência do poder administrativo e do poder científico unificados. Ela se aparenta com o direito penal não apenas sob o ângulo da sanção, mas também porque se fundamenta nas idéias de infração, de responsabilidade e de afastamento da Regra. As palavras mestras da educação sanitária, do trabalho social e da prevenção sócio-sanitária - "a responsabilidade dos indivíduos" - e sua "autonomização", ilustram bem este fenômeno. No contexto da troca liberal, a medicina reconhece a doença, responde ao pedido do doente para trazer 'um estar melhor'. A responsabilidade individual não é posta em dúvida no duplo sentido do termo (procura da causa, procura da responsabilidade); a localização da doença em um lugar que não atinge o eu nem a identidade pessoal, circunscrita em uma parte do corpo cuja norma de funcionamento é autônoma em relação à pessoa (cuja inviolabilidade deve ser preservada), não coloca a pessoa em dúvida. Com a medicina preventiva, a doença como direito não é reconhecida, a saúde é prescrita, a demanda é social e estatal. Ela tem como objetivo, além do 'estar melhor', conduzir à autonomia individual, que na prática equivale a uma adaptação controlada. A doença diz cada vez mais respeito ao eu. É o que se pode constatar como prolongamento da medicina psicossomática derivado da idéia de Groddeck, segundo a qual a doença é a expressão de um conflito entre o id e o ego. $\mathrm{O}$ intervencionismo médico-social tende a arrancar a máscara - esta máscara que

51. A reabilitaçao atual desta noção é justamente o sinal da realidade que ela encobre. 
significava na sua origem etimológica a noção de pessoa e que preservava a sua individuação -, para descobrir os determinismos que fazem a pessoa agir e que a afastam de um modelo ideal prescritivo, por definição inacessível. É nisto que a doença se aparenta mais com o desvio.

O vagabundo era punivel com a prisão porque não dispunha de bens pelos quais responder. Ele era responsável por não ter laços nem bens. $O$ vagabundo moderno, constituído pela questão social, acumulando sobre sua pessoa diferentes motivos de desvio, é tido como responsável pelos males de que é vítima. É a sua responsabilidade que o torna perigoso. Sua infração é ser desviante na origem de seu ser - origem social, psicológica ou biológica. O objetivo é justamente dar-lhe autonomia e responsabilizá-lo, trabalhando sobre seu eu a partir de uma demanda presumidamente escondida por detrás do seu sofrimento ou do seu pedido de socorro.

2) A lei sócio-penal apresenta, em relação à lei liberal, pelo menos em seu enunciado de princípio, esta diferença: ela não possui caráter universal. A unidade da Sociedade devia ser preservada pela lei única para todos, fundada na igualdade revelada e natural. A lei jurídica, enquanto regra universal, está hoje em declínio em proveito da lei científica que retira seu alcance universal de sua eficiência empírica. A lei jurídica universal continha um princípio e uma fonte de inspirações e aspirações humanas; a lei científica é, em primeiro lugar, uma arma. A validade do princípio da regra jurídica podia ser verificada na experiência cotidiana dos indivíduos, pelo uso comum de sua razão. O caráter experimental e verificável da lei pelo círculo dos cientistas, como símbolo de seu alcance universal, institui o estatuto separado do conhecimento e, além disso, a diferença entre os indivíduos em função de sua utilidade e de sua eficiência social. O princípio experimental descobre a ordem cósmica, a teleonomia de um mundo em luta perpétua pela sobrevivência, ao mesmo tempo em que revela, praticando-se, as diferenças naturais. $\mathrm{O}$ direito à diferença toma-se um princípio fundador de unidade simbólica, legitimando uma hierarquia naturalizada.

Numerosos autores vem constatando, há várias décadas, o declínio da lei jurídica enquanto regra universal, em proveito das práticas administrativas e de um direito estatutário em rápido desenvolvimento. Esse princípio de diferenciação social pela profissionalização tem o seu correspondente no nível da gestão do social na esfera sócio-sanitária. A partir da produção de leis científicas, a medicina e as ciências do Homem em geral participam da definição de indicadores sociais da diferença, estabelecendo correspondências estatísticas entre pertences sócio-profissionais e riscos de morbidez social, psicológica e orgânica. Fazendo isso, elas contribuem para a diferenciação de situações sociais naturalizadas para o tratamento social difercnciado que deve respunder a elas. 
No século XVIII, as assistências públicas são consideradas uma correção necessária da desigualdade econômica e social que contradiz de forma evidente demais os princípios liberais de igualdade e de liberdade. Segundo Condorcet, "a existência da sociedade econômica separada do Estado complica o problema da igualdade e coloca o problema da igualdade real distinta da igualdade formal; a desigualdade de riqueza, de situação e de instrução testemunham desta separação. A igualdade real implica então o direito à ajuda positiva da sociedade. As assistências públicas são uma dívida sagrada da sociedade." 52

Este termo será retomado pela Declaração dos Direitos do Homem e do Cidadão em seu artigo 21. Trata-se de uma dívida tão sagrada quanto o direito de propriedade, ao qual os burgueses do século XVIII não queriam renunciar e que contradizia a afirmação do princípio de igualdade entre os homens. É a dívida dos proprietários e dos grupos protegidos por sua instrução, sua riqueza e sua situação, que não quiseram se despojar de direitos adquiridos. Ela será estendida, com a Seguridade Social, à doença, à velhice e à maternidade, e àqueles que, por sua situação física, estão momentaneamente menos aptos para se protegerem desses riscos.

É justamente essa dívida sagrada, assim como a contradição consciente sobre a qual ela se apóia, que definem o campo de intervenção das profissões cuja vocação é proteger aqueles que são vítimas da desigualdade de oportunidades. E é justamente ela que está na origem de sua situação, de seu discurso e de sua prática divididas. Divisão ilustrada pelo duplo discurso da consciência culpada e da autodenúncia, por um lado, da moralização e da responsabilização, por outro. Os trabalhadores sociais, por sua proximidade com aqueles que ajudam, são particularmente sensíveis a essa contradição, da qual sua profissão é o produto. Contradição por eles repetida, por sua própria posição social em relação àqueles que protegem quando, ao mesmo tempo, ensinam seus clientes a utilizar melhor os seus direitos legítimos e, por outro lado, procuram responsabilizá-los. O mesmo acontece com o sociólogo ou com qualquer outro profissional da gestão do social, que procura em sua prática aproximar-se de seu objeto, e cuja consciência culpada só é comparável à obstinação de denunciar as instituições de enclausuramento e de normalização.

Para aliviar o peso da dívida, a solução considerada com freqüência consiste em devolver o fardo ao credor: assim, o discurso da Proteção Social tem como duplo o da educação cívica e da responsabilidade. Jogando com os conceitos de igualdade de oportunidades e do direito à diferença, ele reconhece a marginalidade,

52. GURVITCH G., L'idé du Drolt soclal, op. cit. 
querendo ao mesmo tempo reduzi-la e evitá-la, e contradiz o discurso sobre a igualdade de oportunidades através dos dispositivos de seleção social e de caminhos que estabelece. $O$ universo da dívida sagrada é também aquele mais sombrio do direito adquirido, da auto-defesa e da insegurança. $O$ favorecimento de tais noções torna-se maior na medida em que afirma com menos clareza política a ética social que fundamenta a Proteção Social. De fato, o historicismo surge como o ponto de convergência entre a crise do direito natural e a filosofia política moderna. Esta crise pôde estender-se à filosofia enquanto tal (pela única razão, diz E. Bloch, dela ter sido totalmente politizada ao longo dos últimos séculos). O historicismo, fazendo triunfar o ponto de vista subjetivista e relativista do pensamento, contribui para o enfraquecimento do pensamento político, no sentido em que este é a emanação de uma cena pública na qual a crítica é feita reciprocamente por cidadãos igualmente dotados de razão. Este estatuto relativista do pensamento e o ponto de vista subjetivista da necessidade podem legitimar as idéias de segurança e de proteção. Eles não podem fundamentar a filosofia social de um sistema de real solidariedade que tem como objetivo a igualdade de oportunidades. A noção de necessidade, longe de desembocar em uma filosofia política, tende antes a fechar cada grupo de interesses e cada indivíduo em torno de sua singularidade e de seus direitos adquiridos. Ela favorece a filosofia do lucro.

A idéia de igualdade enquanto ponto de vista ético fundador, porém, está sempre na ordem do dia. As idéias de direito à diferença e de igualdade de oportunidades são a sua expressão contemporânea. São uma tentativa de superação da aplicação formal que foi feita historicamente do princípio de igualdade. Elas só podem convergir para o sentido que lhes demos se as ciências do homem e do ser vivo, que contribuíram para a difusão do historicismo e do positivismo enquanto pensamento dominante na cena política e filosófica, estiverem em condições de aceder ao estágio filosófico, isto é, a um pensamento livre que se dedica à procura das condições da possibilidade da política e da história.

\section{IV - O CORPO E A HISTÓRIA, O ERRO E A CRÍTICA}

Já evocamos a aparição, na nossa sociedade, deste fenômeno cultural que faz do corpo o ponto de partida e de chegada da regra e do sentido. Sentido sem história, contemporâneo da sujeição imposta pelo positivismo e pelo historicismo. Aqui, a política é relegada a um princípio de exterioridade (em relação ao sujeito), caixa preta reguladora universal e imutável do acaso e da necessidade, da origem e do fim, que tem como única finalidade a sua manutenção, indiferente à nossa condição de sujeitos mortais. $\mathrm{O}$ corpo, simplesmente por ser mortal $\mathrm{e}$ às vezes doente, tende a concentrar em torno de si a cena onde se desenvolve a possibilidade da história 
como último lugar de resistência de uma sociedade mais do que nunca tentada pela anti-história.

J. Patocka, nos seus Essais Héretiques ${ }^{53}$, demonstra que a guerra como experiência (a experiência individual do front) é a única experiência de liberdade absoluta e só tem sentido em si mesma. Todas as idéias de socialismo, de progresso, de emancipação e de democracia só podem ganhar seu sentido pleno se procederem dessa experiência e a ela retornarem. Parece-nos que a prova dessa transformação do sentido da vida que se choca aqui ao nada, a um limite intransponível onde tudo muda, essa experiência de liberdade - apenas o corpo pode vivê-la em tempos de paz, quando sua vida está ameaçada. Ele é o único em posição, em um século onde "a guerra integra a paz sob o aspecto da desmobilização" ${ }^{4}$, de colocar a questão do sentido. É desse modo que ele se caracteriza como lugar de subversão.

Assim, ao se afastar da norma de saúde, ele questiona a relação que liga o sujeito à sociedade, o sentido tal como definido pelas ciências do homem e do ser vivo. Como na sociedade Wolof ou na sociedade dos Zande, o sentido encarnado na relação social impõe sua tirania a partir da doença. Na nossa sociedade, como entre os Wolof, existe uma defasagem entre o comportamento submetido à norma e a doença como sanção. Na nossa sociedade, a eventualidade é a inclusão em uma determinada classe estatística de risco dependente de uma intervenção particular. De fato, a estatística não diz nada sobre os casos individuais. Ela dá a lei geral, mas não a lei do determinismo em particular. Segundo os casos, a simples inclusão em uma classe de risco legitimará a intervenção social. Por exemplo, a de uma puericultura no domicílio de uma família de risco para verificar, em nome de um programa preventivo e de necessidades bem compreendidas, que os comportamentos dos pais são normais. As mulheres grávidas, enquanto grupo de risco, serão convocadas em grupos para serem educadas: aprender o que se deve ou não fazer com uma criança, antes de serem novamente convocadas para as visitas obrigatórias pós-natais. A eventualidade é também a ausência de um comportamento voluntário e intencional, tal como o exige a lei penal para imputar a infração penal ao autor de um delito; é a premeditação, em função da origem de um destino desviante em relação à origem normal (pela hereditariedade biológica, pelo trauma ou simplesmente pela origem social), que justifica uma intervenção social.

De modo global, o intervencionismo sócio-médico permite ler nas pessoas, em seu ser ou sobre seu corpò estigmatizado pelo desvio, a submissão à lei sócio-

53. PATOCKA J., Essais hérétiques sur la philosophie de l'Histoire, Verdier (Ed.), Lagrasse, 1981.

54. PATOCKA J., Essais hérétiques sur la philosophie de l'Histoire, op. cit. p. 143. 
penal dos indivíduos reduzidos a máquinas de produzir desejosas. A infração por ele estabelecida é a de não desejar curar, é o comprometimento da lei da produção. Este intervencionismo culpabilizante condena aquele que, através desta nova forma de desvio, coloca em jogo o seu corpo, fonte última de liberdade, para desafiar a relação social, fazendo voltar ainda mais a finalidade desta "máquina desejosa" contra a produção de sua própria vida.

A esperança, seja de redenção, de cura ou de paz com sua consciência, supõe o direito de crítica e a crença de que a história não pára no último pensamento produzido. $\mathrm{O}$ historicismo nega a história e, à crítica, prefere a demonstração dos especialistas. A lei jurídica é acompanhada, no direito liberal, por direitos de defesa e de debates públicos e contraditórios. Nos domínios de intervenção da lei sóciopenal, o segredo profissional (mas a interdisciplinaridade e a hierarquia interna deste sistema permitem conjunto da estrutura, menos o interessado, de saber tudo), a ausência do interessado $e$ a ausência de defesa constituem a regra. A crítica supõe um laço entre o uso público do raciocínio e a constituição de uma cena política pública onde os interessados ou seus representantes podem debater sobre o que diz respeito ao seu futuro coletivo. Ela pressupõe este estatuto objetivo da razão. A necessidade deste lado foi esclarecida, como vimos, por J. Habermas, em relação ao século XVIII, a propósito da aparição do espaço público que permitiu a derrubada do poder real. Ernst Bloch, a propósito da infração trágica no teatro grego, nos mostra que a esperança está ligada à possibilidade da crítica, à possibilidade, para o sujeito, de desafiar um destino predeterminado: “A infração trágica, mesmo naquilo em que seu déficit humano tem de mais visível, está ainda ligado ao que é legítimo na ação fatal, ao que, em outras palavras, é melhor do que a ordem presente com a qual ela entra colisão. Fazendo aparecer isto, a tragédia quebra a corrente da infração, da culpa e da expiação, pelo desafio e pela esperança. Ela retira do Deus do castigo a sua superioridade. Mas para isso era preciso uma condição exterior: a de que a palavra crítica fosse exercida; que o diálogo e o discurso fossem firmados em outro lugar, nas assembléias do povo e principalmente no tribunal. A imagem do procedimento penal penetrou na tragédia; ela retomou o mito da infração e da expiação como um tipo de debate judiciário." 55

A infração predeterminada é então a negação do direito de crítica e do princípio democrático carregado por ela. A lei prescritiva se opõe ao sujeito criador de sua história, reduzindo-o a sujeitar-se a uma lei que ele é incapaz de definir. O sujeito tutelado, menor diante das instituições detentoras do nomos, não tem outro destino a não ser submeter-se ao seu império.

55. BLOCH E., Droit naturel et dignité humaine, op. cit. 
Nessas condições, o declínio da cena pública e política (há décadas, os juristas do direito constitucional se interrogam sobre as causas do enfraquecimento do papel político dos parlamentos e sobre os remédios a serem aplicados) assinala o empobrecimento da noção de pessoa como valor, como sede da autonomia do pensamento, da vontade e da criatividade.

O nascimento de uma esfera social é o produto da profissionalização da sociedade e do prolongamento do Estado, e não a simples tradução jurídica de um direito social, de uma organização social 'espontânea' desejada por G. Gurvitch, e para cuja formalização, segundo ele, a sociologia jurídica teria podido contribuir. Assim, o debate em torno das ciências do homem, para saber se e em que condição elas podem ser portadoras de promessas de liberação e gerar mais justiça social, se reduz, mais uma vez ainda, ao velho debate que opõe liberalismo e estatismo. A alternativa é ainda opor um idealismo liberal, cujas críticas são conhecidas demais, a um prolongamento do poder do Estado através de um controle social sem limites?

O objetivo deste artigo consistia em mostrar que o liberalismo conduz, com todos os males dos quais pode-se legitimamente acusá-lo, um princípio liberador no qual se inscreve hoje a batalha dos direitos do homem. A afirmação dos princípios de igualdade e de liberdade carrega consigo a necessidade da categoria do político em si, categoria não redutível à simples superestrutura organizacional, produto histórico direto e necessário do sistema capitalista. A existência do político aparece ligada à idéia de direito natural, isto é, à necessidade de dar à filosofia o seu lugar na organização social, ponto de vista negado pelo historicismo positivista. Tratava-se de mostrar que o ponto de vista filosófico e o do direito natural não são redutíveis a simples ideologias, reflexos de situações econômicas de classe, mas que a visão que os homens têm do mundo ao seu redor, as interrogações que eles colocam, participam do arbitrário cultural e social, isto é, de uma possibilidade de criação histórica. Neste sentido, as representações de si mesmo, da relação de si com o outro, de si com o mundo natural, os modos de formalização destas representações, participam deste nível cultural criador.

Nasnossas representações contemporâneas, o corpo ocupa um lugar peculiar, pois, de lugar de prova individual comum de finitude e do sentido primeiro para $o$ sujeito, ele se tornou o terreno de aplicação privilegiado da Lei das relações sociais e do sentido coletivo da vida em sociedade.

Resta imaginar de que modo as 'novas práticas contra-culturais' em relação ao corpo e suas novas medicinas, as diversas experiências de espaços 'neutros' no exterior das instituições ou à sua margem, inauguradas por profissionais do setor médico-social e portadoras de novas cenas de trocas entre sujeitos, podem contribuir, no seu nível, para abrir o caminho da filosofia e da cena política. Resta imaginar também de que modo subverter o sentido instrumental que as ciências e 
as técnicas projetam sobre o seu objeto, em uma perspectiva de sujeição, a fim de desviá-lo nesta mesmo direção.

\section{RESUMO}

\section{A Lei e o Corpo}

Partindo do conceito do arbitrário cultural, onde se relativiza a categoria de enfermidade e se evidencia a inserção desta no campo da significação, o ensaio discute a problemática da autonomia do organismo e da saúde como constituinte da lei, para estabelecer então as relações entre as categorias de causalidade, desvio e ordem jurídica, que se desdobra na discussão entre corpo e história.

\section{ABSTRACT}

\section{Law and the Body}

Starting from the concept of cultural arbitrariness, where the category of "sickness" is relativized and where its insertion in the realm of meaning is evidenced, this essay discusses the issue of the autonomy of the organism and of health as components of law. It goes on to establish relations between the notions of causality, deviance, and judicial order, leading into a discussion of the body and history.

\section{RESUME}

\section{La Loi et le Corps}

C'est à partir du concept d'arbitraire culturel, où la maladie est relativisée en tant que catégorie et où son insertion dans le champ de la signification est mis en évidence, que cet essai analyse la problématique de l'autonomie de l'organisme et de la santé comme une des dimensions de la loi. Il reproduit également les relations existantes entre les notions de causalité, de déviance et d'ordre juridique qui se dégagent de la perception que l'on a du corps au long de l'histoire. 